\title{
ANTIMICROBIAL, INSECTICIDAL, AND ANTIRADICAL ACTIVITY OF SOLANUM VIRGINIANUM L. (SOLANACEAE)
}

\author{
PRASHITH KEKUDA TR ${ }^{1}$, RAGHAVENDRA HL ${ }^{2 *}$, RAJESH MR ${ }^{1}$, AVINASH HC ${ }^{1}$, ANKITH GN ${ }^{1}$, KARTHIK KN ${ }^{1}$ \\ ${ }^{1}$ Department of Microbiology, S.R.N.M.N College of Applied Sciences, N.E.S Campus, Shivamogga, Karnataka, India. ${ }^{2}$ Department of \\ Biochemistry, School of Medicine, Wollega University, Nekemte, Ethiopia. Email: raghu.biogem@gmail.com
}

Received: 23 May 2017, Revised and Accepted: 21 July 2017

\section{ABSTRACT}

Objectives: The present study was conducted to determine antimicrobial, antiradical, and insecticidal activity of methanolic extract of the whole plant of Solanum virginianum L. (Solanaceae).

Methods: Extraction of shade dried and powdered plant material was carried out by maceration process. Antibacterial and antifungal activities of extract were determined by agar well diffusion and poisoned food technique, respectively. Antiradical activity of extract was assessed by 1,1-diphenyl2-picrylhydrazyl (DPPH) and 2,2-azinobis 3-ethylbenzothiazoline 6-sulfonate (ABTS) free radical scavenging assays. Insecticidal activity, in terms of larvicidal activity, was evaluated against $2^{\text {nd }}$ and $3^{\text {rd }}$ instar larvae of Aedes aegypti.

Results: The extract exhibited inhibitory activity against all bacteria. Gram-positive bacteria showed greater susceptibility to extract when compared to Gram-negative bacteria. The extract was effective in inhibiting the mycelial growth of all test fungi with marked activity against Curvularia sp. and Alternaria sp. The extract scavenged DPPH and ABTS radicals dose dependently with an inhibitory concentration value of 45.66 and $7.37 \mu$ g/ml, respectively. The extract showed concentration-dependent larvicidal activity with high lethal activity observed against $2^{\text {nd }}$ instar larvae with lethal concentration value of $0.82 \mathrm{mg} / \mathrm{ml}$.

Conclusion: In suitable form, the plant can be used as an effective agent against microbial infections and oxidative damage and to control insect vectors which transmit several diseases.

Keywords: Solanum virginianum, Agar well diffusion, Poisoned food technique, 1,1-diphenyl-2-picrylhydrazyl, 2,2-azinobis 3-ethylbenzothiazoline 6-sulfonate, Aedes aegypti.

(C) 2017 The Authors. Published by Innovare Academic Sciences Pvt Ltd. This is an open access article under the CC BY license (http://creativecommons. org/licenses/by/4. 0/) DOI: http://dx.doi.org/10.22159/ajpcr.2017.v10i11.20180

\section{INTRODUCTION}

Plants have been used for many purposes such as timber, food, and medicine worldwide since time immemorial. Worldwide, many plants have been extensively used by rural population and tribal communities as an indispensable source of medicine. It is estimated that around $80 \%$ of world population rely on medicinal plants for their primary health-care needs. Traditional medicinal practitioners use these plants singly or in some formulations to treat several ailments. Plants are an integral part of various systems of indigenous medicine such as Ayurveda, Unani, and Siddha. Countries such as China, India, Pakistan, Sri Lanka, and Thailand extensively use a number of medicinal plants for therapy against several diseases. The curative properties of plants are mainly due to the presence of a range of secondary metabolites such as phenolics, alkaloids, and terpenes which have been distributed in various parts of plants. Many plants have provided lead compounds for the development of pharmacologically active drugs. Drugs such as aspirin, digoxin, quinine, and morphine have been derived from plants [1-6].

The genus Solanum comprises of herbs or shrubs, rarely small trees, and sometimes subscandent or climbing unarmed or prickly. The leaves are entire, lobed, or pinnatifid. Flowers are in lateral or terminal cymes. Fruit is a globose or elongated berry [7]. Solanum virginianum L. (Solanum surattense Burm. f.; Solanum xanthocarpum Schrad. \& $\mathrm{H}$. Wendl.) is a diffuse and very prickly undershrub belonging to the family Solanaceae (Fig. 1). It is found growing commonly in various regions of the world on sandy soils and is distributed throughout India. It is commonly called as yellow-berried nightshade in English, kantakari in Sanskrit, and nelagulla in Kannada. It is one of the members of dashamula of Ayurveda. The prickles are straight, compressed, and yellowish. The leaves are up to $10 \times 6 \mathrm{~cm}$, ovate or elliptic with acute apex, and pinnatified half-way down. Petioles have long pickles, and base is very unequal. Flowers are in few-flowered cymes. Calyx is prickly with ovate or lanceolate lobes. Corolla is violet in color and approximately $2 \mathrm{~cm}$ in diameter. Berry is globose, $2 \mathrm{~cm}$ in diameter, and yellow or white with green blotches [7-10].

A wide range of phytochemicals such as alkaloids, phenolics, flavonoids, sterols, saponins, glycosides, fatty acids, tannins, and amino acids have

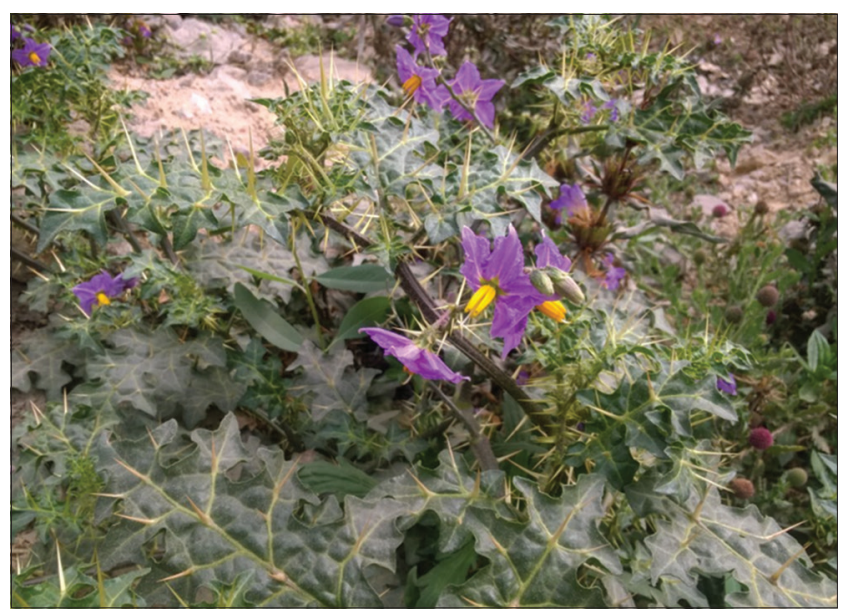

Fig. 1: Solanum virginianum $\mathrm{L}$. 
been identified from different parts of the plant. The plant is extensively used in various systems of medicine including Ayurveda. The plant is used traditionally to treat asthma, chest pain, leucoderma, scorpion bite, and sterility in women. Roots are much used in medicine. The oil from seeds is used to treat arthritis. The ash from dried fruits is used to relieve toothache [7-14]. The plant is shown to exhibit various bioactivities such as antimicrobial, anthelmintic, antioxidant, hemolytic, anti-inflammatory, antidiabetic, cytotoxic, phytotoxic, hepatoprotective, and immunostimulatory activities [10,14,15-19]. In the present study, we investigated antimicrobial, insecticidal, and antiradical activity of extract from whole plant of $S$. virginianum.

\section{METHODS}

\section{Chemicals and media}

Culture media, namely, nutrient agar, nutrient broth, and potato dextrose agar (PDA) and chemicals, namely, methanol, ascorbic acid, potassium persulfate, dimethyl sulfoxide (DMSO), and chloramphenicol were purchased from HiMedia, Mumbai, India. Chemicals, namely, 1,1-diphenyl-2-picrylhydrazyl (DPPH) and 2,2-azinobis 3-ethylbenzothiazoline 6-sulfonate (ABTS) were purchased from Sigma Chemical Co., USA.

\section{Collection and identification of plant}

The plant was collected at a place called Indira Nagar, Shivamogga, during January 2016. The plant was identified on the basis of its characteristics by referring flora $[7,11]$ and with the help from Prof. D. Rudrappa, Department of Botany, S.R.N.M.N College of Applied Sciences, Shivamogga, Karnataka.

\section{Extraction}

The whole plants (comprising of root, stem, leaves, flowers, and fruits) were selected for this study. The plants were washed using water to remove debris and dust particles and dried under shade. The shade dried plant material was powdered and extracted using methanol by maceration process in which the plant powder is left in methanol for $48 \mathrm{hrs}$ with occasional stirrings [20]. The crude extract was stored in refrigerator until use. The yield and color of extract were $7.65 \%$ and dark green, respectively.

\section{Antibacterial activity of methanol extract of $S$. virginianum}

Antibacterial potential of extract was evaluated against four Grampositive bacteria, namely, Staphylococcus aureus NCIM 5345, Staphylococcus epidermidis NCIM 2493, Bacillus subtilis NCIM 2063, and Bacillus cereus NCIM 2016 and three Gram-negative bacteria, namely, Escherichia coli NCIM 2065, Pseudomonas aeruginosa NCIM 2200, and Salmonella typhimurium NCIM 2501. The pure cultures of test bacteria were maintained on nutrient agar slants in refrigerator. The broth cultures of test bacteria were prepared by transferring the pure cultures of test bacteria aseptically into sterile nutrient broth tubes followed by incubating the tubes overnight at $37^{\circ} \mathrm{C}$. The broth cultures were then used to assess their susceptibility to leaf and flower extract by agar well diffusion [3]. The broth cultures were swab inoculated on sterile nutrient agar plates aseptically. Using a cork borer (sterilized by dipping in alcohol followed by flaming), wells of $8 \mathrm{~mm}$ diameter were punched and the wells were labeled and filled with $100 \mu \mathrm{l}$ of extract (25 mg/ml of DMSO), chloramphenicol (reference antibiotic, $1 \mathrm{mg} / \mathrm{ml}$ of sterile distilled water), and DMSO. The plates were allowed to stand for 30 minutes and were incubated at $37^{\circ} \mathrm{C}$ for $24 \mathrm{hrs}$. The zones of inhibition formed around the wells were measured.

\section{Antifungal activity of methanol extract of $S$. virginianum}

Antifungal potential extract was evaluated by poisoned food technique against three seed-borne fungi, namely, Alternaria sp., Curvularia sp., and Fusarium sp. isolated previously from moldy grains of sorghum. The pure cultures of test fungi were maintained on PDA plates in refrigerated condition. The control (without extract) and poisoned (1 mg extract $/ \mathrm{ml}$ of medium) PDA plates were inoculated aseptically with the test fungi, and the plates were incubated in upright position for $96 \mathrm{hrs}$ at room temperature. The diameter of fungal colonies was measured, and the antifungal effect, in terms of extent of inhibition of radial growth (\%) of test fungi, was determined using the following formula:

Inhibition of radial growth $(\%)=(\mathrm{C}-\mathrm{T} / \mathrm{C}) \times 100$, where $\mathrm{C}$ and $\mathrm{T}$ refer to colony diameter of test fungi on control and poisoned plates, respectively [20].

\section{Antiradical activity of methanol extract of $S$. virginianum}

Two in vitro assays, namely, DPPH and ABTS assay were carried out to investigate radical scavenging efficacy of methanol extract of S. virginianum.

\section{DPPH free radical scavenging activity}

We performed DPPH free radical scavenging activity of extract by employing the protocol of Kekuda et al. [20]. $1.0 \mathrm{ml}$ of different concentrations $(6.25-200 \mu \mathrm{g} / \mathrm{ml})$ of extract in methanol was mixed with $3.0 \mathrm{ml}$ of DPPH $(0.004 \%$ in methanol) radical solution in separate tubes and incubated in the dark for 30 minutes. The absorbance was measured in a spectrophotometer at $517 \mathrm{~nm}$. Methanol replacing extract served as control. Ascorbic acid was used as standard. Scavenging activity was calculated using the following formula:

Scavenging of DPPH radicals $(\%)=(\mathrm{C}-\mathrm{T} / \mathrm{C}) \times 100$, where $\mathrm{C}$ and $\mathrm{T}$ refer to absorbance of DPPH control and absorbance of DPPH in presence of extract/ascorbic acid, respectively. The inhibitory concentration $\left(\mathrm{IC}_{50}\right)$ value was calculated. IC $\mathrm{I}_{50}$ denotes the concentration of extract required to scavenge $50 \%$ of DPPH radicals.

\section{ABTS radical scavenging activity}

We evaluated antiradical activity, in terms of scavenging of ABTS radicals, of extract using the protocol of Kekuda et al. [20]. $1.0 \mathrm{ml}$ of different concentrations of extract $(6.25-200 \mu \mathrm{g} / \mathrm{ml}$ of methanol) was mixed with $3.0 \mathrm{ml}$ of ABTS radical solution. The absorbance was measured in a spectrophotometer at $730 \mathrm{~nm}$ after completion of incubation in the dark for 30 minutes. Ascorbic acid was used as standard. The radical scavenging activity of extract was calculated using the following formula:

Scavenging activity $(\%)=(\mathrm{C}-\mathrm{T} / \mathrm{C}) \times 100$, where $\mathrm{C}$ is the absorbance of the ABTS solution without extract/ascorbic acid and T is the absorbance of ABTS solution in the presence of extract/ascorbic acid. The $\mathrm{IC}_{50}$ value was calculated. $\mathrm{IC}_{50}$ denotes the concentration of extract required to scavenge $50 \%$ of ABTS free radicals.

\section{Larvicidal activity of methanol extract of $S$. virginianum}

The insecticidal potential of extract was tested on the basis of its larvicidal effect against $2^{\text {nd }}$ and $3^{\text {rd }}$ instar larvae of Aedes aegypti. 25 larvae were transferred into conical flasks containing $50 \mathrm{ml}$ of dechlorinated water with different concentrations of extract $(0.0-2.0 \mathrm{mg} / \mathrm{ml})$. Mortality of larvae (\%) was recorded after $24 \mathrm{hrs}$ and was calculated using the formula:

Mortality of larvae (\%) = (number of dead larvae/number of total larvae) $\times 100$ [21]. Lethal concentration $\left(\mathrm{LC}_{50}\right)$ value was calculated. $\mathrm{LC}_{50}$ indicates the concentration of extract required to cause $50 \%$ mortality of larvae.

\section{Statistical analyses}

All the experimental results are mentioned as mean \pm standard deviation of three trials. The $\mathrm{LC}_{50}$ and $\mathrm{IC}_{50}$ values were obtained by the linear regression analysis.

\section{RESULTS AND DISCUSSION}

\section{Antibacterial activity of extract of $S$. virginianum}

Plants and formulations containing plants have been extensively used as medicine since time immemorial. An immense interest on the search for plants and their products as antibacterial agents has been triggered in scientific community in the recent years. This is mainly because of several drawbacks associated with the use of antibiotics such as side 
effects, high cost, and rapid development of resistance in pathogens. It has been shown that plants and their metabolites exhibit promising antimicrobial activity [22-25]. Antibacterial activity can be determined by various methods such as disk diffusion, agar well diffusion, and broth dilution. Among these, agar well diffusion method is one of the widely used in vitro assays for determining antibacterial activity of plant extracts [3,24,26-28].

In the present study, we determined antibacterial activity of extract of $S$. virginianum by agar well diffusion assay. The presence of zone of inhibition around the well was considered positive for antibacterial activity. The extract was effective in inhibiting all test bacteria but to a varied extent. Marked and least inhibitory activity was observed against B. subtilis and S. typhimurium, respectively. Among Grampositive bacteria, B. subtilis was inhibited to higher extent while others were inhibited to more or less similar extent. In case of Gramnegative bacteria, P. aeruginosa and S. typhimurium were susceptible to highest and least extent, respectively. Inhibitory activity displayed by standard antibiotic was higher than that of extract. DMSO did not cause inhibition of any of the test bacteria (Table 1). Overall, Gram-positive bacteria exhibited marked susceptibility to extract as well as antibiotic when compared to Gram-negative bacteria. The presence of an outer membrane in Gram-negative bacteria might be responsible for the low susceptibility as it might have acted as an additional barrier for the entry of extract/antibiotic. In a previous study, Sheeba [27] showed concentration-dependent inhibitory activity of leaf extract against a panel of bacteria. Pardhi et al. [15] revealed potent antibacterial activity of ethanol extract of the whole plant against bacteria when compared to other solvent extracts. In another study, Dinanath and Gurumeet [16] found marked antibacterial activity of root extract when compared to leaf extract. Recently, Rana et al. [14] observed concentrationdependent inhibitory activity of leaf extract against Gram-positive and Gram-negative bacteria. The study of Kumar et al. [18] revealed marked antibacterial activity of leaf extract when compared to fruit extract.

\section{Antifungal activity of extract of $S$. virginianum}

Fungi are ubiquitous and are responsible for causing a number of diseases in crops leading to huge economic losses in severe cases. Management of fungal diseases by chemical method suffers from several drawbacks such as high cost, environmental pollution, adverse effects on humans, and emergence of resistant pathogens. This alarming situation triggered immense interest in scientific community to search alternates for controlling fungal diseases. Plants and plant-based formulations have shown promising antifungal activity [20,29-31]. One of the most widely used antifungal assays is poisoned food technique. Here, poisoning of medium with the sample results in considerable reduction in the mycelial growth of test fungi if the sample has antifungal principles in it. Reduction in colony diameter on poisoned plates is an indication of antifungal activity. This method has been successfully used by several researchers to evaluate antifungal activity of plant extracts [20,31-34].

In the present study, we evaluated antifungal potential of extract of S. virginianum by poisoned food technique, and the result is shown in

Table 1: Antibacterial activity of methanol extract of Solanum virginianum

\begin{tabular}{llll}
\hline \multirow{2}{*}{ Test bacteria } & \multicolumn{2}{l}{ Zone of inhibition in cm } \\
\cline { 2 - 4 } & Extract & Antibiotic & DMSO \\
\hline Staphylococcus aureus & $1.30 \pm 0.26$ & $3.43 \pm 0.06$ & $0.0 \pm 0.00$ \\
Staphylococcus epidermidis & $1.30 \pm 0.17$ & $3.43 \pm 0.12$ & $0.0 \pm 0.00$ \\
Bacillus cereus & $1.30 \pm 0.10$ & $3.57 \pm 0.12$ & $0.00 \pm 0.00$ \\
Bacillus subtilis & $1.40 \pm 0.00$ & $3.27 \pm 0.06$ & $0.00 \pm 0.00$ \\
Escherichia coli & $1.13 \pm 0.12$ & $2.90 \pm 0.00$ & $0.00 \pm 0.00$ \\
Salmonella typhimurium & $1.07 \pm 0.06$ & $3.10 \pm 0.17$ & $0.00 \pm 0.00$ \\
Pseudomonas aeruginosa & $1.20 \pm 0.10$ & $3.07 \pm 0.06$ & $0.00 \pm 0.00$ \\
\hline
\end{tabular}

Table 2. The extract was effective in inhibiting fungal growth as evidenced by a considerable reduction in the colony growth on plates poisoned with extract. Extract inhibited the mycelial growth of all fungi to $>40 \%$. Among fungi, marked susceptibility was recorded against Curvularia sp. (61.29\% inhibition) and Alternaria sp. (61.14\% inhibition) while Fusarium sp. was inhibited to less extent ( $43.47 \%$ inhibition). It has been shown that various solvent extracts of fruit exhibited antifungal activity [35]. Methanol extract of leaf was more active in inhibiting Candida albicans and Aspergillus niger when compared to chloroform, petroleum ether, and aqueous extracts [26]. Leaf extracts were able to inhibit Aspergillus species and C. albicans dose dependently [36]. The study carried out by Mamta et al. [37] showed the potential of flower, stem, and fruit extract to inhibit $A$. niger and A. flavus. The study by Shiv et al. [38] showed dose-dependent inhibition of C. albicans by hexane extract of leaf, whereas other extracts did not show any inhibitory activity. More recently, fruit extract was shown to suppress the growth of clinical dermatophytes dose dependently to higher extent when compared to root extract [34].

\section{DPPH radical scavenging activity of extract of $S$. virginianum}

The assay involving scavenging of DPPH free radicals was developed by Blois, and it has been routinely used to evaluate free radical scavenging activity of various types of samples including plant extracts. The assay is considered as a valid, accurate, easy, and economical, and the results are reproducible. DPPH is a stable and nitrogen-centered organic free radical and has a strong absorption at 515-520 $\mathrm{nm}$ in alcoholic solution, and it does not need special methods for its generation as in case of ABTS radicals which needs to be generated before assay. Substances capable of donating hydrogen atom (often termed antioxidants) will reduce the purple-colored DPPH to DPPHH which has yellow-colored [20,39-41]. In the present study, we screened the potential of various concentrations of whole plant methanolic extract of S. virginianum to scavenge DPPH radicals. We monitored bleaching of color of DPPH radical solution in the presence of varying concentrations of extract at $517 \mathrm{~nm}$. The extract scavenged DPPH radicals in a dose-dependent manner with an $\mathrm{IC}_{50}$ value of $45.66 \mu \mathrm{g} / \mathrm{ml}$. Scavenging of radicals was $>50 \%$ at extract concentration of $50 \mu \mathrm{g} / \mathrm{ml}$ and higher. At $200 \mu \mathrm{g} / \mathrm{ml}$ concentration, extract scavenged DPPH radicals to $>90 \%$ (Fig. 2). Ascorbic acid scavenged DPPH radicals more efficiently $\left(\mathrm{IC}_{50}\right.$ value of $\left.8.89 \mu \mathrm{g} / \mathrm{ml}\right)$ than that of methanol extract of $S$. virginianum. Although the scavenging

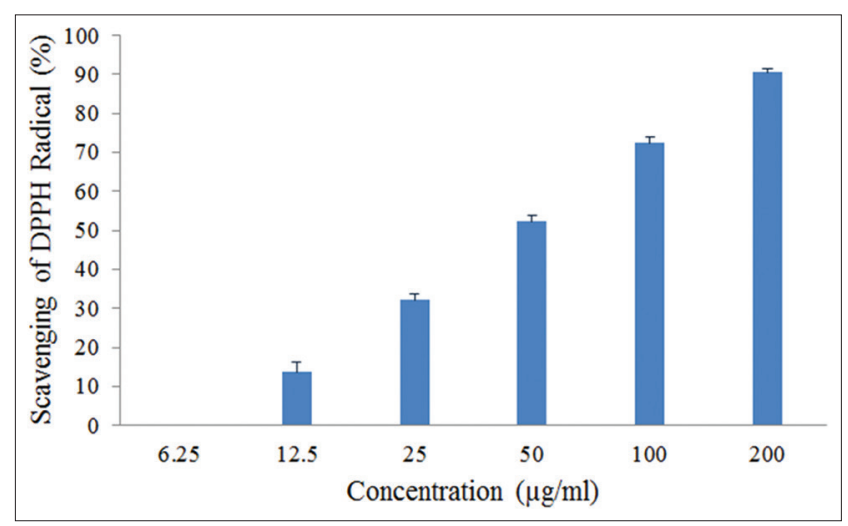

Fig. 2: Scavenging of 1,1-diphenyl-2-picrylhydrazyl radicals by Solanum virginianum

Table 2: Colony diameter of test fungi on control and poisoned plates

\begin{tabular}{lll}
\hline Test fungi & \multicolumn{2}{l}{ Colony diameter in $\mathbf{~ c m}$} \\
\cline { 2 - 3 } & Control & Extract \\
\hline Curvularia sp. & $4.47 \pm 0.06$ & $1.73 \pm 0.12$ \\
Fusarium sp. & $4.37 \pm 0.12$ & $2.47 \pm 0.06$ \\
Alternaria sp. & $5.07 \pm 0.12$ & $1.97 \pm 0.06$ \\
\hline
\end{tabular}




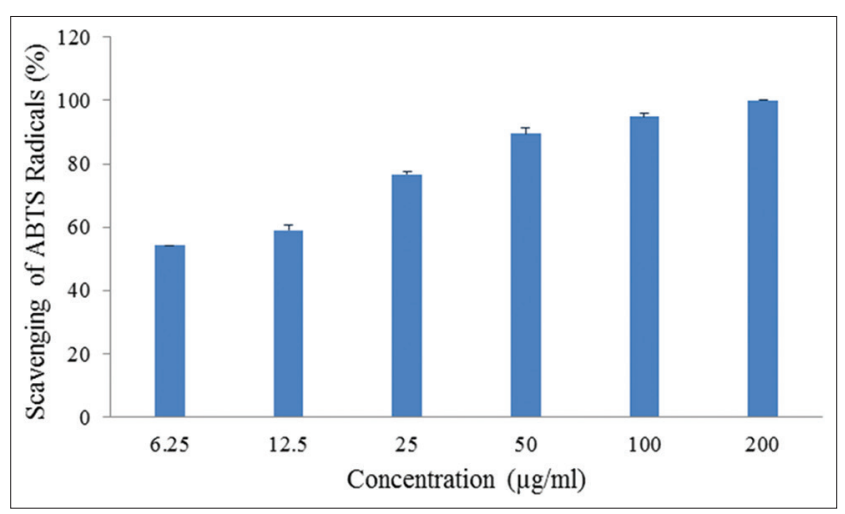

Fig. 3: Scavenging of 2,2-azinobis 3-ethylbenzothiazoline 6-sulfonate radicals by Solanum virginianum

of DPPH radicals by extract was less when compared to ascorbic acid, it is evident that the extract contains antioxidant principles possessing hydrogen-donating property which could act as free radical scavengers. In earlier studies, Shah et al. [17] and Muruhan et al. [41] observed dosedependent scavenging of DPPH radicals by fruit extract and leaf extract, respectively. Archana and Jocob [42] found dose-dependent scavenging of DPPH radicals by root extract with an $\mathrm{IC}_{50}$ value of $52 \mu \mathrm{g} / \mathrm{ml}$. In a recent study by Rajakumari and Selvi [19], the ethyl acetate extract of fruit was shown to exhibit scavenging of DPPH radicals.

\section{ABTS radical scavenging activity of extract of $S$. virginianum}

Like DPPH assay, the assay involving scavenging of ABTS radicals is another popular in vitro assay. In this assay, it is required to generate the radical as it is not ready to use as in case of DPPH assay. ABTS radical was generated by mixing ABTS stock solution $(7 \mathrm{mM})$ with potassium per sulfate $(2.45 \mathrm{mM})$ and leaving the mixture in the dark for about $16 \mathrm{hrs}$ at room temperature. The resulting solution was diluted using distilled water to an absorbance of 0.7 at $730 \mathrm{~nm}$. A substance having electrondonating nature will reduce the blue-green ABTS radical solution to colorless neutral form $[20,41]$. In the present study, we determined radical scavenging nature of methanol extract of $S$. virginianum by ABTS assay. The extract was found to scavenge the radicals in a concentration-dependent manner with an $\mathrm{IC}_{50}$ value of $7.37 \mu \mathrm{g} / \mathrm{ml}$. A scavenging potential of $>50 \%$ was observed at all concentrations of extracts tested and $>90 \%$ scavenging of radicals was observed at extract concentration $100 \mu \mathrm{g} / \mathrm{ml}$ and higher (Fig. 3). Ascorbic acid was found to scavenge ABTS radicals more efficiently $\left(\mathrm{IC}_{50}\right.$ value $3.59 \mu \mathrm{g} / \mathrm{ml}$ ) when compared to methanol extract of $S$. virginianum. Although the extract of $S$. virginianum displayed low scavenging potential than that of ascorbic acid, it is evident that the extract possesses the electrondonating property, and hence, the extract could serve as free radical scavengers. In an earlier study, Muruhan et al. [41] found dosedependent scavenging of ABTS radicals by leaf extract and was marked when compared to standard.

\section{Insecticidal activity of extract of $S$. virginianum}

Mosquitoes occur worldwide and play an important and vital role as vectors of several dreadful diseases such as dengue, malaria, filariasis, yellow fever, and Japanese encephalitis. In the recent years, the dengue viruses which are transmitted by the $A$. aegypti have become a great agony for the international public health. Control strategies involve the use of synthetic insecticides but increase in resistance toward the synthetic insecticides among mosquito populations have become more challenging. A. aegypti showed its resistance toward chemicals such as dichlorodiphenyltrichloroethane, organophosphate, and pyrethroid. Besides, the use of chemicals also causes environmental pollution and side effects against humans and other organisms. This situation driven the quest of alternative environment friendly pesticides from natural origin. Botanicals have shown to be effective against insect pests $[21,43-46]$.

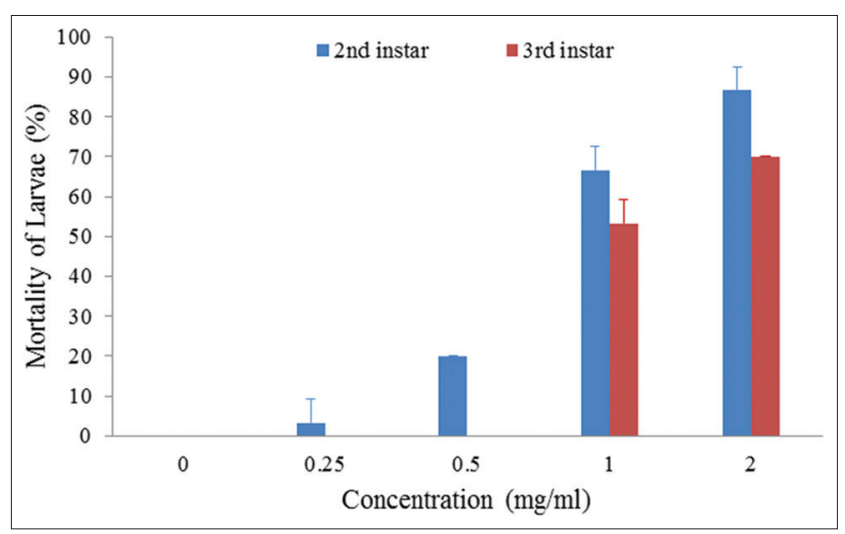

Fig. 4: Mortality of larvae at different concentrations of Solanum virginianum

The result of insecticidal activity, in terms of larvicidal effect, of extract of $S$. virginianum is shown in Fig. 4. The extract was shown to cause dose-dependent mortality of larvae of A. aegypti. The extract was more effective in causing mortality of $2^{\text {nd }}$ instar larvae $\left(\mathrm{LC}_{50}\right.$ value $\left.0.82 \mathrm{mg} / \mathrm{ml}\right)$ when compared to $3^{\text {rd }}$ instar larvae $\left(\mathrm{LC}_{50}\right.$ value $1.11 \mathrm{mg} / \mathrm{ml}$ ) as revealed by lower $\mathrm{LC}_{50}$ value. At 0.25 and $0.50 \mathrm{mg} / \mathrm{ml}$ concentration, extract did not cause larvicidal effect against $3^{\text {rd }}$ instar larvae. At extract concentration of $1 \mathrm{mg} / \mathrm{ml}$, a mortality of $>50 \%$ of $2^{\text {nd }}$ and $3 \mathrm{rd}$ instar larvae was observed. At extract concentration of $2 \mathrm{mg} / \mathrm{ml}$, mortality of $2^{\text {nd }}$ and $3^{\text {rd }}$ instar larvae was $86.67 \%$ and $70.00 \%$, respectively. In a previous study, Bansal et al. [47] evaluated insecticidal activity of various parts of the plant against several mosquito vectors. Methanolic extracts were superior than aqueous extracts. Mohan et al. [48] showed that the combination of fenthion and petroleum ether extract acted synergistically against Culex quinquefasciatus at a ratio of $1: 1$. In another study, Kumar et al. [49] showed that leaf extract displays larvicidal and pupicidal effect against $C$. quinquefasciatus. It is clear from our study that the extract of $S$. virginianum exhibits marked larvicidal potential at earlier stages of development of larvae of A. aegypti. Similar observation was made in an earlier study by Kumar et al. [49].

\section{CONCLUSION}

The whole plant extract of $S$. virginianum showed antibacterial activity which indicated its possible use in the treatment of diseases caused by pathogenic bacteria. Marked antifungal potential of extract observed in this study can be exploited to develop natural antifungal agents which can be used in the management of seed-borne fungi and fungal diseases of plants. The present study highlighted potent antiradical activity of S. virginianum, and hence, the plant can be used as natural antioxidant having effectiveness in the prevention and control of oxidative damage caused by free radicals. In suitable form, the plant can be used as a natural insecticide to control insect vectors that transmit arboviral diseases such as dengue and others.

\section{ACKNOWLEDGMENTS}

Authors would like to thank the Head of the Department of Microbiology and Principal of S.R.N.M.N College of Applied Sciences, for providing facilities to conduct work. Authors would like to thank N.E.S for moral support. Authors also thank Prof. D. Rudrappa for assisting in collection and identification of plant material.

\section{REFERENCES}

1. Pal SK, Shukla Y. Herbal medicine: Current status and the future. Asian Pac J Cancer Prev 2003;4(4):281-8.

2. Kassaye KD, Amberbir A, Getachew B, Mussema Y. A historical overview of traditional medicine practices and policy in Ethiopia. Ethiop J Health Dev 2006;20(2):127-34.

3. Vinayaka KS, Nandini KC, Rakshitha MN, Martis R, Shruthi J, Hegde SV, et al. Proximate composition, antibacterial and anthelmintic 
activity of Capsicum frutescens (L.) var. Longa (Solanaceae) leaves. Pharmacogn J 2010;2(12):486-91.

4. Nagori K, Sharma M, Agrawal A, Agarwal AK, Sharma A, Verma H, et al. General awareness on Allopathic, Ayurvedic and Homeopathic system of medicine in Chhattisgarh, India. Int J Pharm Pharm Sci 2011:3(4):159-62.

5. Sahu PK, Masih V, Gupta S, Sen DL, Tiwari A. Ethnomedicinal plants used in the healthcare systems of tribes of Dantewada, Chhattisgarh India. Am J Plant Sci 2014;5:1632-43.

6. Swamy SH, Asha MM, Chaithra M, Vivek MN, Kambar Y, Kekuda PT. Antibacterial activity of flower extract of Caesalpinia pulcherrima, Delonix regia and Peltaphorum ferrugineum against urinary tract pathogens. Int Res J Biol Sci 2014;3(4):80-3.

7. Bhat GK. Flora of South Kanara. Mangalore: Akriti Prints; 2014. p. 723.

8. Rita P, Animesh DK. An updated overview on Solanum xanthocarpum Schrad and Wendl. Int J Res Ayurveda Pharm 2011;2(3):730-5.

9. Rane MH, Sahu NK, Ajgoankar SS, Teli NC, Verma DR. A holistic approach on review of Solanum virginianum. L. Res Rev J Pharm Pharm Sci 2014;3(3):1-4.

10. Reddy NM, Reddy RN. Solanum xanthocarpum chemical constituents and medicinal properties: A review. Sch Acad J Pharm 2014;3(2):146-9.

11. Manjunatha BK, Krishna V, Pullaiah T. Flora of Davanagere District, Karnataka, India. New Delhi: Regency Publications; 2004. p. 281-2.

12. Kayani S, Ahmad M, Zafar M, Sultana S, Khan MP, Ashraf MA, et al. Ethnobotanical uses of medicinal plants for respiratory disorders among the inhabitants of Gallies - Abbottabad, Northern Pakistan. J Ethnopharmacol 2014;156:47-60.

13. Kumar PR. Ethno medicinal plants used for oral health care in India. Int J Herb Med 2014;2(1):81-7.

14. Rana S, Prakash V, Sagar A. Antibacterial activity of Solanum xanthocarpum leaf extract. Int J Curr Microbiol Appl Sci 2016;5(4):323-8

15. Pardhi P, Jain AP, Ganeshpurkar A, Rai G. Anti-microbial, anti-oxidant and anthelmintic activity of crude extract of Solanum xanthocarpum. Pharmacogn J 2010;2(11):400-4.

16. Dinanath PD, Gurumeet WC. Antibacterial, antioxidant and antiinflammatory studies of leaves and roots of Solanum xanthocarpum. Unique J Ayurvedic Herb Med 2013;1(3):59-63.

17. Shah MA, Khan H, Muhammad N, Khan F, Shahnaz, Muhammad A, et al. Cytotoxic, antioxidant and phyototoxic effect of Solanum surattense Burm $\mathrm{f}$ fruit extracts. Int $\mathrm{J}$ Pharmacogn Phytochem 2013;28(2):1154-8.

18. Kumar SR, Hariprasanth RJ, Siddharth PM, Gobinath M, Rajukutty C. Evaluation of the antioxidant, antimicrobial, antidiabetic and hemolytic activity of organically grown Solanum nigrum and Solanum xanthocarpum. Int J Curr Pharm Rev Res 2016;7(5):296-9.

19. Rajakumari M, Selvi KK. Effect of fruit of Solanum xanthocarpum as immuno stimulant on fish Channa striatus. Int J Sci Technol 2016;4(12):76-87.

20. Kekuda TR, Raghavendra HL, Solomon T, Duressa D. Antifungal and antiradical potential of Moringa stenopetala (Baker f.) Cufod (moringaceae). J Biosci Agric Res 2016;11(1):923-9.

21. Murthy JM, Rani PU. Biological activity of certain botanical extracts as larvicides against the yellow fever mosquito, Aedes aegypti. L. J Biopestic 2009;2(1):72-6.

22. Telban B. The role of medical ethno botany in ethno medicine: A New Guinea example. J Ethnobiol 1988;8(2):149-69.

23. Cowan MM. Plant products as antimicrobial agents. Clin Microbiol Rev 1999;12(4):564-82.

24. Valgas C, de Souza SM, Smânia EF, Smânia A Jr. Screening methods to determine antibacterial activity of natural products. Braz J Microbiol 2007;38(2):369-80.

25. Hassan BA. Medicinal plants (importance and uses). Pharm Anal Acta 2012;3:10.

26. Saini V, Middha A, Kinger HK, Rathore MS, Rathore SG. Antibacterial and antifungal activities of Solanum xanthocarpum leaf. Int J Plant Sci 2006;1(2):367-8

27. Sheeba E. Antibacterial activity of Solanum surattense Burm. f.
Kathmandu Univ J Sci Eng Technol 2010;6(1):1-4

28. Balouiri M, Sadiki M, Ibnsouda SK. Methods for in vitro evaluating antimicrobial activity: A review. J Pharm Anal 2016;6:71-9.

29. Albera A, Lemessa F, Muleta D. The antifungal activity of some medicinal plants against coffee berry disease caused by Colletotrichum kahawae. Int J Agric Res 2011;6(3):268-79.

30. Prince L, Prabakaran P. Antifungal activity of medicinal plants against plant pathogenic fungus Colletotrichum falcatum. Asian J Plant Sci Res 2011;1(1):84-7.

31. Neela FA, Sonia IA, Shamsi S. Antifungal activity of selected medicinal plant extract on Fusarium oxysporum Schlecht the causal agent of fusarium wilt disease in tomato. Am J Plant Sci 2014;5:2665-71.

32. Minz S, Samuel CO, Tripathi SC. The effect of plant extracts on the growth of wilt causing fungi Fusarium oxysporum. IOSR J Pharm Biol Sci 2012;4(1):13-6.

33. Rodino S, Butu M, Petrache P, Butu A, Cornea CP. Antifungal activity of four plants against Alternaria alternata. Sci Bull F Biotechnol 2014;18:60-5.

34. Shubha KS, Sumana K, Lakshmidevi L. Antifungal activity of Solanum xantocarpum Sch and Wend and Picrorhiza kurroa Royle ex Benth against some clinical dermatophytes. Int J Curr Microbiol Appl Sci 2016;5(2):236-44

35. Abbas K, Niaz U, Hussain T, Saeed MA, Javaid Z, Idrees A, et al. Antimicrobial activity of fruits of Solanum nigrum and Solanum xanthocarpum. Acta Pol Pharm 2014;71(3):415-21.

36. Perumal B, Murugesan S. Study of antimicrobial activity of Solanum xanthocarpum sp. Int J Curr Trend Res 2015;4(1):23-8.

37. Mamta, Pimpalgaonkar R, Dalei J. Qualitative evaluation of phytochemicals and antifungal activity of "Solanum xanthocarpum" (Schrad. \&Wendl.). IOSR J Pharm Biol Sci 2016;11(3):99-104.

38. Shiv G, Gaherwal S, Shrivastava CS, Wast N. Antifungal activity of Aegle marmelos, Calotropis procera and Solanum xanthocarpum extract against Aspergillus niger, Candida albicans and Phenerochaete chrysosporium. Eur J Exp Biol 2015;5(2):81-9.

39. Blois MS. Antioxidant determinations by the use of a stable free radical. Nature 1958;181:1199-200.

40. Kedare SB, Singh RP. Genesis and development of DPPH method of antioxidant assay. J Food Sci Technol 2011;48(4):412-22.

41. Muruhan S, Selvaraj S, Viswanathan PK. In vitro antioxidant activities of Solanum surattense leaf extract. Asian Pac J Trop Biomed 2013;3(1):28-34

42. Archana C, Jacob J. Phytochemical investigation and anti-oxidant studies on the roots of Solanum xanthocarpum Linn. Asian J Phytomed Clin Res 2015;3(1):32-6.

43. Harve G, Kamath V. Larvicidal activity of plant extracts used alone and in combination with known synthetic larvicidal agents against Aedes aegypti. Indian J Exp Biol 2004;42(12):1216-9.

44. Ramar R, Ignacimuthu S, Manonmani P, Murugan K. Adulticidal activity of botanical oils by impregnated paper assay against Culex quinquefasciatus say. Int J Pharm Pharm Sci 2017;9(5):156-60.

45. Yousaf A, Zuharah WF. Lethal response of the dengue vectors to the plant extracts from family Anacardiaceae. Asian Pac J Trop Biomed 2015;5(10):812-8

46. Ruiz-Guerrero R, Rodríguez-Pérez MA, Norzagaray-Campos M. Toxicity of Mexican native plant extracts against larvae of Aedes aegypti (Diptera: Culicidae). Asian Pac J Trop Biomed 2015;5(4):287-91.

47. Bansal SK, Singh KV, Kumar S. Larvicidal activity of the extracts from different parts of the plant Solanum xanthocarpum against important mosquito vectors in the arid region. J Environ Biol 2009;30(2):221-6.

48. Mohan L, Sharma P, Srivastava CN. Combination larvicidal action of Solanum xanthocarpum extract and certain synthetic insecticides against filarial vector, Culex quinquefasciatus (SAY). Southeast Asian J Trop Med Public Health 2010;41(2):311-9.

49. Mahesh Kumar P, Murugan K, Kovendan K, Subramaniam J, Amaresan D. Mosquito larvicidal and pupicidal efficacy of Solanum xanthocarpum (Family: Solanaceae) leaf extract and bacterial insecticide, Bacillus thuringiensis, against Culex quinquefasciatus say (Diptera: Culicidae). Parasitol Res 2012;110(6):2541-50. 